\title{
Stability of a Seabird Population in the Presence of an Introduced Predator
}

\section{Stabilité d'une population d'oiseaux de mer en présence d'un prédateur introduit}

Heather L. Major, Alexander L. Bond, Ian L. Jones and Cari J. Eggleston

\begin{abstract}
We hypothesized that although large populations may appear able to withstand predation and disturbance, added stochasticity in population growth rate $(\lambda)$ increases the risk of dramatic population declines. Approximately half of the Aleutian Islands' population of Least Auklets (Aethia pusilla) breed at one large colony at Kiska Island in the presence of introduced Norway rats (Rattus norvegicus) whose population erupts periodically. We evaluated two management plans, do nothing or eradicate rats, for this colony, and performed stochastic elasticity analysis to focus future research and management. Our results indicated that Least Auklets breeding at Kiska Island had the lowest absolute value of growth rate and more variable $\lambda$ 's (neither statistically significant) during 2001-2010, when compared with rat-free colonies at Buldir and Kasatochi islands. We found variability in the annual proportional change in population size among islands with Kiska Island having the fastest rate of decline, $78 \%$ over 20 years. Under the assumption that the eradication of rats would result in vital rates similar to those observed at ratfree Buldir and Kasatochi islands, we found the projected population decline decreased from $78 \%$ to $24 \%$ over 20 years. Overall, eradicating rats at Kiska Island is not likely to increase Least Auklet vital rates, but will decrease the amount of variation in $\lambda$, resulting in a significantly slower rate of population decline. We recommend the eradication of rats from Kiska Island to decrease the probability of dramatic population declines and ensure the future persistence of this important colony.
\end{abstract}

RÉSUMÉ. Nous avons émis l'hypothèse voulant que, même si des populations élevées semblent capables de résister à la prédation et aux perturbations, la stochasticité augmente le risque d'un déclin démographique important lorsqu'elle est prise en compte dans le taux de croissance des populations ( $\lambda$ ). Près de la moitié de la population de Stariques minuscules (Aethia pusilla) qui niche sur les îles Aléoutiennes se concentre dans une grande colonie sur l'île Kiska, en présence de rats surmulots (Rattus norvegicus) introduits, dont la population explose périodiquement. Nous avons évalué deux plans de gestion pour cette colonie de stariques - soit ne pas intervenir, soit éradiquer les rats - et effectué des analyses d'élasticité stochastique dans le but d'orienter la recherche et la gestion futures. Nos résultats montrent que le taux de croissance des Stariques minuscules qui nichent sur l'île Kiska est plus faible et plus variable (de façon non statistiquement significative) comparativement aux colonies sans rats des îles Buldir et Kasatochi pour la période 2001-2010. Nous avons constaté que le changement annuel de la taille des populations variait selon les îles, l'île Kiska étant celle qui présente le taux de déclin le plus rapide, soit $78 \%$ sur 20 ans. En faisant l'hypothèse selon laquelle l'éradication des rats entraînerait des taux vitaux comparables à ceux observés sur les îles sans rats Buldir et Kasatochi, nous avons observé que le déclin projeté de la population diminuait de 78 à $24 \%$ sur 20 ans. Dans l'ensemble, l'éradication des rats sur l'île Kiska ne permettrait vraisemblablement pas d'augmenter les taux vitaux moyens du Starique minuscule, mais permettrait de diminuer leur variabilité, ce qui conduirait à un taux de déclin de la population significativement plus lent. Nous recommandons l'éradication des rats sur l'île Kiska afin de diminuer le risque d'un déclin démographique important et d'assurer la pérennité de cette importante colonie.

Key Words: Aleutian Islands; island conservation; stage-class matrix model; viability analysis

\section{INTRODUCTION}

Over evolutionary time, species adapt to natural fluctuations in environmental features, e.g., climate, prey availability, and selection should favor variation in those life-history strategies, e.g., survival and reproductive success, that do not cause large fluctuations in population growth rate $(\lambda)$ or individual fitness
(Doak et al. 2005). The occurrence of nonnatural, i.e., anthropogenic, disturbances can result in highly variable demographic vital rates, but the direction of population change depends on the covariance among matrix elements, and the type of changes in demographic variability (Lewontin and Cohen 1969, Doak et al. 2005, Morris et al. 2006). Therefore,

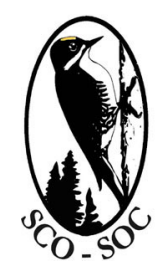

Sponsored by the Society of Canadian Ornithologists and Bird Studies Canada Parrainée par la Société des ornithologistes du Canada et Études d'oiseaux Canada

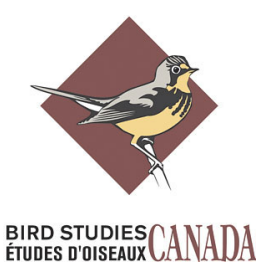


to manage a population effectively, understanding any factor that increases variability in $\lambda$ is important.

Least Auklets (Aethia pusilla) are small ( $\sim 85 \mathrm{~g})$, socially monogamous seabirds that breed in small rock crevices at a few large colonies on the Aleutian Islands and other remote islands in the Bering and Okhotsk Seas (Bédard 1969, Knudtson and Byrd 1982, Kondratyev et al. 2000, Bond et al. 2013). They are one of the most abundant seabirds in the North Pacific Ocean, have relatively high adult survival, approximately $84 \%$, an annual clutch size of one, and an average reproductive success of 0.5-0.7 chicks fledged per pair per year (Bond et al. 2013). There are several million Least Auklets breeding in the Aleutian Islands, with perhaps half of these breeding at Kiska Island (Byrd et al. 2005).

Norway rats (Rattus norvegicus) are opportunistic predators and can rely heavily on seabirds. Stomach content and stableisotope analyses revealed that Least Auklets made up at least $11 \%$ (range of $0-50 \%$ ) of rat diet at the Kiska Island auklet colony (Major et al. 2007, Eggleston 2010). Observed hoarding of adult Least Auklets early in the breeding season at Kiska Island may have severe conservation implications because older, more experienced seabirds generally begin attending colonies earlier in the breeding season, before younger breeders and subadults (Hedgren 1980, Piatt et al. 1990, Jones 1992). Early season hoarding by rats may therefore selectively remove older, more experienced individuals contributing to low auklet reproductive rates (Major and Jones 2005). Indirect effects are therefore likely playing a large and important role in Least Auklet annual survival and reproductive success at Kiska Island (Major et al. 2006). Furthermore, disturbance and egg predation at Kiska Island results in early abandonment of Least Auklet adults at the colony site, contributing to higher than normal adult survival in years of low reproductive success, and lower adult survival in years with average reproductive success (Major et al. 2006). Increased variability in vital rates at Kiska Island due to disturbance and predation by introduced rats was therefore expected.

The objective of this study was to understand how increased variability in vital rates due to an introduced predator affects a large population, using the case of Least Auklets breeding in the western Aleutian Islands as an example. We hypothesized that increased variability in vital rates due to predation and disturbance by introduced rats at Kiska Island was driving population trends. Specifically, we predicted that $\lambda$ would not differ between Kiska Island, and nearby Kasatochi and Buldir islands, free of introduced predators, but yearly variation in vital rates, survival, and recruitment would be greatest at Kiska Island, resulting in an increased rate of population decline. In addition, we evaluated the stochastic elasticities of $\lambda$ to a change in Least Auklet matrix elements to better understand where future research should be focused (Heppell et al. 2000). We used population models to evaluate two management options, (1) do nothing or (2) eradicate rats, and assessed the viability of the Least Auklet population breeding at Kiska Island by projecting population trends under a varying number of 'bad years,' i.e., when environmental fluctuations and/or rat predation/disturbances are greatest resulting in the lowest $\lambda$ observed.

\section{METHODS}

\section{Study site}

Our study was conducted on three islands located in a $585 \mathrm{~km}$ span across the Aleutian archipelago: Buldir, Kasatochi, and Kiska in the Alaska Maritime National Wildlife Refuge (AMNWR; Fig. 1). Buldir Island (52 $\left.23^{\prime} \mathrm{N}, 175^{\circ} 55^{\prime} \mathrm{E}\right)$ located in the Near Islands group is 1929 ha and 656 meters above sea level. There are an estimated 140,000 breeding Least Auklets at Buldir Island and no introduced predators (Byrd et al. 2005). Kasatochi Island $\left(52^{\circ} 11^{\prime} \mathrm{N}, 175^{\circ} 31^{\prime} \mathrm{W}\right)$ located in the Andreanof Islands group is 505 ha and 314 meters above sea level. There are an estimated 15,000 breeding Least Auklets at Thundering Talus, Kasatochi Island (Byrd et al. 2005). In 1984, introduced Arctic foxes (Vulpes lagopus) were eradicated from Kasatochi Island releasing breeding birds from predation and disturbance (Ebbert and Byrd 2002). In August 2008, a catastrophic volcanic eruption buried the colony site at Kasatochi Island in ash (Williams et al. 2010). Kiska Island $\left(52^{\circ} 08^{\prime} \mathrm{N}, 177^{\circ} 37^{\prime} \mathrm{E}\right)$ located in the Rat Islands group is 27,769 ha and 1220 meters above sea level. Despite the introduction of Norway rats during military occupation in the 1940s, there are an estimated 1.2 million breeding Least Auklets on two lava domes at Kiska Island (Murie 1959, Byrd et al. 2005). This site also supports over 600,000 breeding Crested Auklets (Aethia cristatella) that are similarly exposed to rat predation (Byrd et al. 2005, Bond et al., in press). In 1987, Arctic foxes were eradicated from Kiska, possibly resulting in an escalation of rat predation and disturbance on auklets as has been seen in other systems with mesopredators (Rayner et al. 2007).

Fig. 1. Map of the North Pacific Ocean showing the locations of Buldir, Kasatochi, and Kiska islands, Alaska.

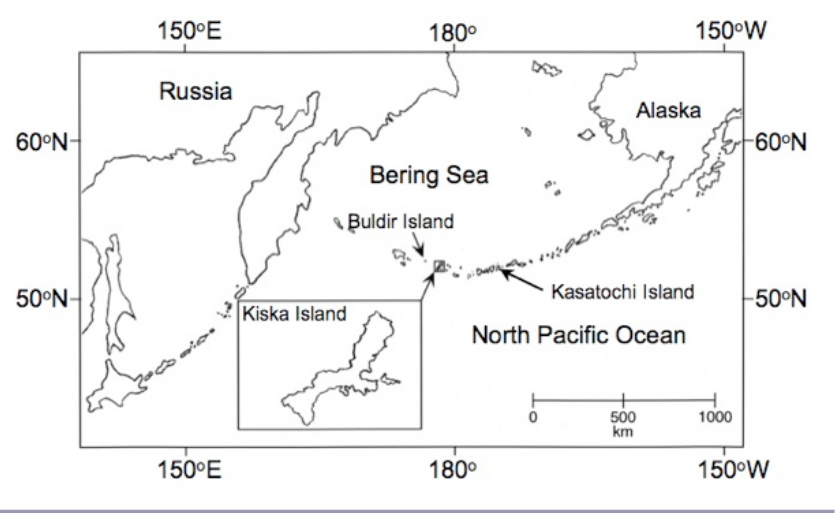


Kiska, Buldir, and Kasatochi islands are experiencing some habitat loss through encroaching vegetation, but Kiska is the only island among the three with an introduced predator. These islands experience similar oceanographic and climate conditions, and have similar vegetation and native predator communities. We therefore believe the effects of anthropogenic-related mortality, i.e., introduced rats, can be determined by comparing the demographic rates of the rataffected Kiska Island population, and the unaffected Buldir and Kasatochi Island populations, as has been done in other studies (Wiese et al. 2004).

\section{Least Auklet demography}

Data on Least Auklet reproductive success, i.e., number of chicks fledged per pair per year, and adult survival from 1990-2010 at Buldir Island, 1996-2007 at Kasatochi Island, and 2001-2010 at Kiska Island, were collected during ongoing, long-term monitoring programs supported by AMNWR (Bond and Jones 2008, Buchheit and Ford 2008, Payne 2008, Tucker et al. 2010, Bond et al. 2011). Data on annual adult survival and/or reproductive success could not be collected at Buldir Island in 1999, Kasatochi Island in 2008, or from Kiska Island in 2005 because of logistical constraints during those breeding seasons.

Reproductive success, i.e., recruitment to the juvenile stage through adult reproduction, was estimated by locating, marking, and monitoring Least Auklet breeding crevices once every four to seven days from late May through early August (Bond et al. 2011). Each nest was assigned a fate after fledging, and reproductive success was calculated as the proportion of total eggs laid that resulted in a fledged chick.

Adult survival analysis was estimated by capturing Least Auklets for marking with color bands, using noose carpets set on the colony surface within a single $50 \mathrm{~m}^{2}$ (surface area) study plot on each island (Jones et al. 2002). Age class, adult or subadult, was determined, but sex of each individual in the sample was unknown because of the absence of sexual dimorphism in Least Auklets. Subadult birds, two-year-olds, identified by criteria described by Jones and Montgomerie (1992) and Jones (1993), were not color banded and not included in survival analyses. Resightings of color-marked auklets were made daily, except during bad weather conditions, from mid-May to early August, which encompassed the birds' laying, incubation, and chick-rearing periods.

Local adult annual survival and recapture rates were estimated using Cormack-Jolly-Seber models and methods as described by Lebreton et al. (1992), Burnham and Anderson (2002), and Jones et al. (2002), with the program MARK (White and Burnham 1999). We defined a global model (Burnham and Anderson 2002, Anderson and Burnham 1999) in which survival and recapture rates were allowed to vary over time and among islands. We restricted our candidate model set to the global model plus 15 reduced parameter models to avoid a large number of models, many with poor fit. We determined the goodness-of-fit of our global model to the data using a parametric bootstrap approach. From these bootstraps, we extracted the mean of the model deviance and extrabinomial variation $(\hat{c})$. The observed deviance and $\hat{c}$ were divided by the mean of the bootstrapped values, and the higher of the two values was taken as the estimate of $\hat{c}$.

We used an information theoretic approach to rank our candidate models using Akaike's information criterion (Akaike 1974) for small sample sizes, correcting for overdispersion by including an estimate of model overdispersion ( $\hat{c})$ for the global model. We used QAIC and $_{c}$ QAIC $c$ weights $\left(w_{i}\right)$ to evaluate model likelihood (Akaike 1974, Burnham and Anderson 2002), and then used model averaging to generate parameter estimates and unconditional standard errors.

Consistent with a postbreeding census, the first annual survival estimate for each island occurs one year after the initial monitoring began and encompasses survival during the following winter and summer. Estimates of annual juvenile survival are unavailable for Least Auklets or any other similarsized alcid species. We used estimates of annual adult survival for juvenile survival, even though adult survival is likely higher than juvenile survival. The consequence of this assumption is likely an underestimation of population declines.

\section{Population model}

\section{Basic matrix analyses}

We developed a Lefkovitch, stage-class matrix model with no density dependence because any density dependent factors, especially those in relation to available habitat, are reflected in the observed vital rates, and a postbreeding census (Lefkovitch 1965, Caswell 2001). This approach simulated the growth of a structured population in an independently and identically distributed stochastic environment, and was used because of the absence of demographic data for each age class. Our life cycle and corresponding population projection matrix (Fig. 2) were split into two stages, juveniles and adults, where juveniles were all prebreeding individuals, and adults were all sexually mature individuals. When individual juveniles survive, they either remain in the juvenile stage or mature into the adult stage, whereas new individuals are added to the juvenile stage through the reproductive output of adults (Fig. 2). Individual adults can survive and remain in the adult stage, but do not mature into another stage. New individuals are added through maturation from the juvenile stage (Fig. 2). Our model year starts on August 1, after the breeding season ends such that the juvenile stage includes all those individuals that fledged prior to August, i.e., all individuals that were recruited into the juvenile stage through the reproductive output of adults, and all those that did not mature into the adult stage. 
Fig. 2. Life cycle graph for the stage-classified model and corresponding population projection matrix for Least Auklets (Aethia pusilla) where $P_{1}$ represents juvenile survival (from fledging through two year olds), $F_{2}$ adult fecundity (includes survival from egg stage through fledging, the proportion of birds breeding, and a clutch size of 0.5$), G_{1}$ maturation (probability of surviving the juvenile phase and becoming an adult), and $P_{2}$ adult survival (all individuals older than two).

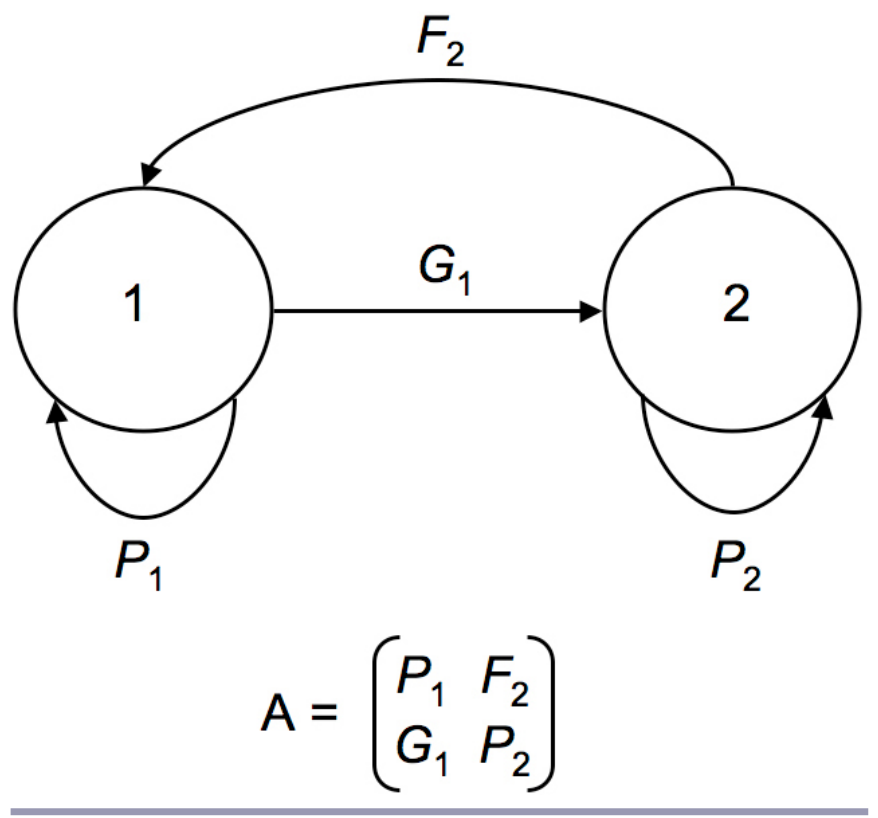

We constructed $352 \times 2$ population projection matrices summarizing the survival, growth, and fecundity of Least Auklets at each of the three islands (Appendix 1) where $\sigma_{i}$ is the annual survival of an individual in stage $i, \gamma_{1}$ the proportion of juveniles that mature into adults, and $T_{\mathrm{i}}$ the time spent in the juvenile stage.

$$
\gamma_{1}=\frac{\left(\sigma_{1} / \lambda\right)^{T_{1}}-\left(\sigma_{1} / \lambda\right)^{T_{1}-1}}{\left(\sigma_{1} / \lambda\right)^{T_{1}}-1}
$$

We used an iterative approach to calculate $\lambda$, where $\lambda$ was set at 1.0 initially, and matrix entries were calculated, i.e., $\gamma_{1}, P_{1}$, $P_{2}, G_{1}$, and $F_{2}$. Using these new matrix values, a second estimate of $\lambda$ was calculated. This approach was repeated until a matrix whose entries were compatible with its own eigenvalues was converged upon (Caswell 2001). We assumed a stable withinstage distribution and calculated:

$$
\begin{gathered}
P_{1}=\sigma_{1}\left(1-\gamma_{1}\right) \\
P_{2}=\sigma_{2}
\end{gathered}
$$

$$
G_{1}=\sigma_{1} \times \gamma_{1}
$$

We used an equation for a birth pulse population with a postbreeding census to calculate fecundity,

$$
F_{2}=r \times 0.7036 \times 0.5
$$

where the proportion of adult stage birds breeding was fixed at 0.7036 (Jones 1992), and clutch size was estimated to be 0.5 (Gaston and Jones 1998) because each breeding pair lays one egg, and this analysis considers individuals. Recruitment to the juvenile stage through adult reproduction $(r)$ was incorporated in the fecundity term as the proportion of nests that produced a fledging.

To test whether stochasticity associated with rats at Kiska Island is driving population declines, we estimated the mean stochastic growth rate $\left(\log \lambda_{\mathrm{s}}\right)$ for each island during 2001-2010 for comparison with the mean $\lambda$ s. Written in MATLAB (Mathworks 2007), this simulation using 50,000 simulated population growth increments, estimated $\log \lambda_{\mathrm{s}}$, which was calculated as:

$$
\log \lambda_{s}=\frac{1}{T} \sum_{t=1}^{T-1} r_{t}
$$

where

$$
r_{t}=\log (\mathrm{n}(\mathrm{t}+1)) \frac{n(t+1)}{n(t)}
$$

is a one-step population growth rate (all logs are base $e$ ). An approximate $95 \%$ confidence interval was then calculated as:

$$
95 \% \mathrm{CI}=\exp \left(\log \lambda_{s} \pm 1.96 \sqrt{\sigma^{2}}\right)
$$

(Caswell 2001, Morris and Doak 2002).

We used a one-way analysis of variance (ANOVA) in SAS 9.2 (SAS Institute 2008) to assess differences in matrix elements among islands during 2001-2010. We also present the results of Levene's test of equal variance to show whether a difference in variances among islands exists.

\section{Elasticity analysis}

We used a program written in MATLAB to assess the stochastic elasticities of $\lambda$ to matrix elements using the mean population projection matrix and the covariance matrix, both calculated using matrix element estimates from all years and islands (Caswell 2001, Morris and Doak 2002), to better direct future research on this colony.

\section{Management options}

Population projection models were run to assess how the two management options, do nothing or eradicate rats, would affect projected population trends. In both models, 5000 simulations were run for 100 years, where each population projection

and 
matrix was given the same probability of being used in any year, and a random number generator and cumulative distribution function were used to draw matrices in each time step. All models were written in MATLAB and included an initial population comprising $60 \%$ adults and $40 \%$ juveniles, based upon the average number of age classes within each stage. We built stochasticity into our models by using vital rates estimated from observed demographic estimates.

We evaluated two management options, do nothing and eradicate rats. The do-nothing model estimated what may happen to the Least Auklet population if vital rates remain similar to those measured during 2001-2010. For comparison, the do-nothing model was also run for Buldir Island during 1990-2000 and 2001-2010, and Kasatochi Island during 1996-2000 and 2001-2006. The eradicate-rats model was run under the assumption that rats were eradicated from Kiska Island and were the sole cause of any differences in observed vital rates between Kiska, and rat-free Buldir and Kasatochi islands. Here all matrix elements from the two rat-free islands were used, i.e., Buldir Island during 1990-2010 and Kasatochi Island during 1996-2007 (Appendix 1), assuming that if rats were eradicated from Kiska Island population, trajectories would be similar to those observed at Buldir and Kasatochi islands. We compared the annual change in population size over 100 years between this model and the do-nothing model using one-way ANOVA with the null hypothesis that annual changes in population size were not different between the two management options. When significant differences were found among groups, post hoc analyses were based on Tukey's studentized range tests.

\section{Population viability}

We assessed the viability of the Least Auklet population at Kiska Island by varying the number of 'bad years,' i.e., observed matrix elements from the population projection matrix from Kiska Island with the lowest $\lambda$, and 'good years,' i.e., observed matrix elements from Buldir and Kasatochi islands during 2000-2010 and 2000-2007, respectively (Appendix 1), in a series of population projection models written in MATLAB. 'Bad years' were added incrementally by increasing the probability of a 'bad year' occurring by $2 \%$ until the probability reached $20 \%$ of the time, and then by $5 \%$ until the probability reached $50 \%$ of the time. For each of the 17 models ( $0-5$ bad years out of 10), 5000 simulations were run for 20 years.

\section{RESULTS}

\section{Least Auklet demography}

Overall, we monitored between 44 and 208 Least Auklet breeding crevices on each island in each year, for a total of 3497 breeding sites over all years. Least Auklet reproductive success ranged between 0.0923 and 0.7500 during 1990-2010, and the mean reproductive success at Buldir, Kasatochi, and Kiska islands was $0.5704(95 \% \mathrm{CI}=0.5195-0.6213), 0.5531(95 \%$ $\mathrm{CI}=0.4754-0.6308)$, and $0.4822(95 \% \mathrm{CI}=0.3724-0.5920)$, respectively. Similarly, Least Auklet reproductive success ranged between 0.0923 and 0.7647 during 2001-2010, and the mean reproductive success at Buldir, Kasatochi, and Kiska islands was 0.6037 (95\% CI $=0.5131-0.6943), 0.5198$ (95\% $\mathrm{CI}=0.4065-0.6331)$, and $0.4822(95 \% \mathrm{CI}=0.3724-0.5920)$, respectively. During 2001-2010, Kiska Island had the lowest reproductive success recorded (0.0923), and Buldir had the highest (0.7500).

Overall, between 0 and 199 individual Least Auklets were marked on each island in each year for a total of 1888 individuals over all years. The top candidate model explaining Least Auklet annual adult survival included the term $\sigma$ (year) $p$ (island*year). This model received $68 \%$ of the total support among candidate models, whereas the second best supported model received $32 \%$ of the total support among candidate models, and included the term $\sigma$ (island*year) $p$ (island*year; Table 1). Least Auklet annual adult survival ranged between 0.6484 and 0.9749 during 1990-2010, and the mean annual adult survival at Buldir, Kasatochi, and Kiska islands was $0.8451(95 \% \mathrm{CI}=0.8059-0.8843), 0.8490(95 \% \mathrm{CI}=$ $0.8132-0.8848)$, and 0.7985 (95\% CI $=0.7266-0.8704)$, respectively. Similarly, Least Auklet annual adult survival ranged between 0.6484 and 0.9551 during 2001-2010, and the mean annual adult survival at Buldir, Kasatochi, and Kiska islands was $0.8535(95 \% \mathrm{CI}=0.8063-0.9007), 0.8490(95 \%$ $\mathrm{CI}=0.7981-0.8999)$, and 0.7985 (95\% CI $=0.7266-0.8704)$, respectively. During 2001-2010, Kiska Island had both the highest and lowest annual adult survival (0.6484 and 0.9551).

Table 1. Top five candidate models in comparison with the global model to assess island and year effects on survival and recapture probabilities of adult Least Auklets (Aethia pusilla) on Buldir, Kasatochi, and Kiska islands during 1990-2010. Model likelihood adjusted for overdispersion by $\hat{c}=1.7314$.

\begin{tabular}{lccc}
\hline \hline Candidate model & $K$ & $\Delta \mathrm{QAIC}_{c}$ & $w_{i}$ \\
\hline$\sigma($ year$) p($ island*year) & 60 & 0.00 & 0.6826 \\
$\sigma$ (island*year) $p$ (island*year) & 77 & 1.53 & 0.3172 \\
$\sigma$ (island) $p$ (island*year) & 43 & 18.35 & 0.0001 \\
$\sigma()$.$p (island*year)$ & 41 & 21.86 & 0.0000 \\
$\sigma($ island*year) $p$ (island) & 57 & 138.44 & 0.0000 \\
\hline
\end{tabular}

\section{Population model}

Basic matrix analyses

Overall, we found that Kiska Island had the lowest mean $\lambda$, the lowest matrix element estimates, and highest variances during 2001-2010 (Table 2). However, we found no significant differences in $\lambda \mathrm{s}$ among islands during these years $\left(\mathrm{F}_{2,19}=\right.$ $1.53, \mathrm{p}=0.24)$, and no evidence of differences among 
Table 2. Summary statistics of the eight years of vital rates $\left(P_{1}\right.$ juvenile survival, $F_{2}$ adult fecundity, $G_{1}$ maturation, and $P_{2}$ adult survival) used in our population projection matrices from Buldir, Kasatochi, and Kiska islands estimated during 2001-2010 (actual estimates are for the years 2002 to 2009).

\begin{tabular}{|c|c|c|c|c|c|c|c|c|c|}
\hline & \multicolumn{3}{|c|}{ Buldir } & \multicolumn{3}{|c|}{ Kasatochi } & \multicolumn{3}{|c|}{ Kiska } \\
\hline & Mean & Min-Max & Variance & Mean & Min-Max & Variance & Mean & Min-Max & Variance \\
\hline$P_{1}$ & 0.4614 & $0.3994-0.5035$ & 0.0011 & 0.4558 & $0.4059-4842$ & 0.0011 & 0.4301 & $0.3542-0.5129$ & 0.0030 \\
\hline$F_{2}$ & 0.2124 & $0.1187-0.2639$ & 0.0021 & 0.1829 & $0.1362-0.2559$ & 0.0021 & 0.1669 & $0.0325-0.2252$ & 0.0040 \\
\hline$G_{1}^{2}$ & 0.3920 & $0.3283-0.4445$ & 0.0013 & 0.3932 & $0.3567-0.4195$ & 0.0006 & 0.3740 & $0.2942-0.4422$ & 0.0032 \\
\hline$P_{2}$ & 0.8535 & $0.7277-0.9354$ & 0.0046 & 0.84900 & $0.7626-0.9037$ & 0.0034 & 0.8041 & $0.6484-0.9551$ & 0.0122 \\
\hline$\lambda^{2}$ & 1.0050 & $0.8851-1.1072$ & 0.0046 & 0.9843 & $0.8678-1.0517$ & 0.0063 & 0.9258 & $0.7805-1.1078$ & 0.0130 \\
\hline
\end{tabular}

variances (Levene's test $\mathrm{F}_{2,17}=1.45, \mathrm{p}=0.26$ ). Additionally, we found no significant differences between mean estimates of juvenile survival $\left(P_{1}: \mathrm{F}_{2,19}=1.10, \mathrm{p}=0.36\right)$, maturation $\left(G_{1}\right.$ : $\left.\mathrm{F}_{2,19}=0.43, \mathrm{p}=0.66\right)$, fecundity $\left(F_{2}: \mathrm{F}_{2,19}=1.44, \mathrm{p}=0.26\right)$, or adult survival $\left(P_{2}: \mathrm{F}_{2,19}=0.74, \mathrm{p}=0.49\right)$ among islands.

We found mean $\log \lambda_{\mathrm{s}}$ of 0.9994 (0.9988-0.999), 0.9823 (0.9816-0.9829), and 0.9245 (0.9236-0.9254) for Buldir, Kasatochi, and Kiska islands, respectively. In every case log $\lambda_{\mathrm{s}}$ was slightly lower than the corresponding mean $\lambda(1.0050$ $[0.9580-1.0520], 0.9843 \quad[0.9145-1.0541]$, and 0.9258 [0.8413-1.0103]), but not statistically different based upon overlapping confidence intervals.

\section{Elasticity analysis}

Stochastic elasticity analysis of the population projection matrices revealed that $\lambda$ was most sensitive to changes in adult survival $\left(P_{2}\right)$, and least sensitive to changes in fecundity $\left(F_{2}\right)$, juvenile survival $\left(P_{1}\right)$, and maturation $\left(G_{1}\right.$; Table 3$)$.

\section{Management options}

The mean annual proportional change in population size among all islands and timeframes, and the Kiska Island eradicate-rats model were significantly different $\left(\mathrm{F}_{5,599}=1521.71, \mathrm{p}<0.001\right)$, as were all pairwise comparisons. At Kiska, a $78 \%$ reduction in population size in 20 years, and a > 99\% reduction in population size over 100 years were predicted, a much greater rate of decrease than was predicted at any other island group (Figs. 3, 4). The eradicate-rats management scenario predicted a $24 \%$ reduction in population size over 20 years, and a $60 \%$ reduction in population over 100 years (Fig. 4), a significant improvement over the current population projections.

\section{Population viability}

Our population viability model showed that with as little as a $6 \%$ chance of a 'bad year' in a 10-year period, a reduction in population size of over $20 \%$ in 20 years may occur (Fig. 5). Furthermore, with as few as 1 'bad year' out of 10, i.e., a $10 \%$ chance of a 'bad year' occurring in any 10-year period, the population may experience a population reduction of at least $35 \%$ (Fig. 5).
Table 3. Mean Least Auklet (Aethia pusilla) vital rate values calculated using data collected at Buldir (1990-2010), Kasatochi (1996-2007), and Kiska (2001-2010) islands, Alaska, and stochastic elasticities $(\mathrm{n}=35)$.

\begin{tabular}{lcc}
\hline \hline Vital Rate & Mean Value & Elasticity \\
\hline$P_{1}$, juvenile survival & 0.4513 & 0.0956 \\
$F_{2}$, adult fecundity & 0.1922 & 0.1117 \\
$G_{1}$, maturation & 0.3871 & 0.1118 \\
$P_{2}$, adult survival & 0.8384 & 0.6648 \\
\hline
\end{tabular}

Fig. 3. Comparison of mean annual proportional change in population size over 100 years at Buldir Island in 1990-2000 and 2001-2010; Kasatochi Island in 1996-2000 and 2001-2006; and Kiska Island Alaska, under current demographic conditions and the hypothesized 'eradicate rats' management plan for Least Auklets (Aethia pusilla). Data are shown as means $\pm 95 \%$ CIs.

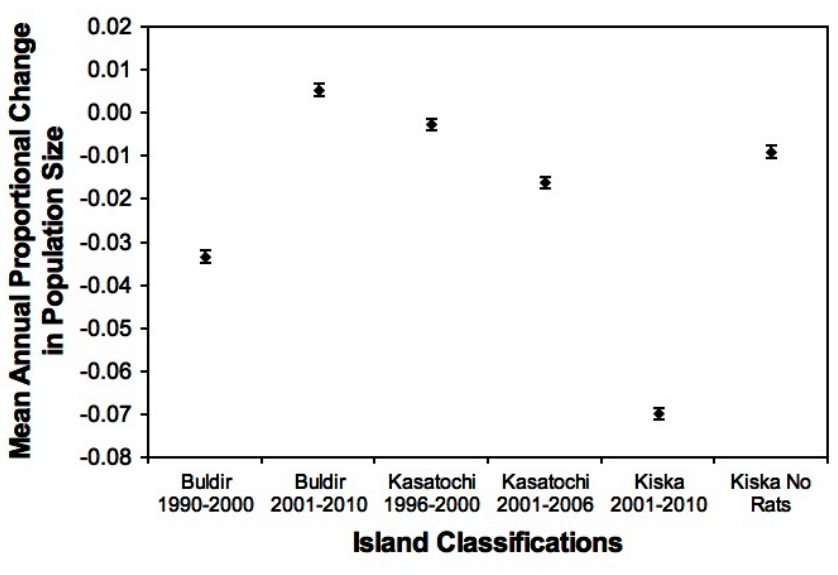


Fig. 4. Comparison of projected changes in population size over 100 years at Buldir, Kasatochi, and Kiska islands, Alaska, under current demographic conditions and the hypothesized 'eradicate rats' management plan for Least Auklets (Aethia pusilla).

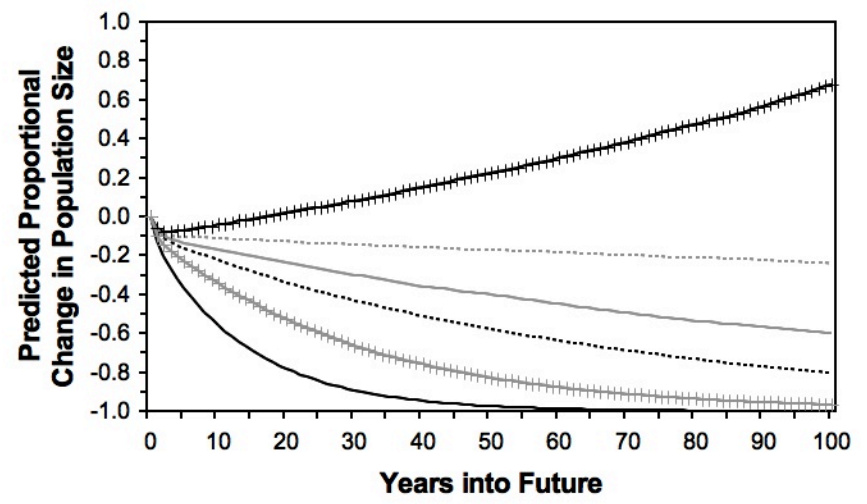

—- Buldir 2001-2010 ‥ - Kasatochi 2001-2007 —— Kiska 2001-2010 _- Buldir 1990-2000 ... - Kasatochi 1996-2000 _— Kiska No Rats

Fig. 5. Comparison of the projected proportional change in population size of Least Auklets (Aethia pusilla) at Kiska Island, Alaska, shown as means for 17 population projection matrices with an increasing number of 'bad years,' i.e., years with the lowest observed population growth rate at Kiska Island. All other matrices were constructed using data recorded at Kasatochi and Buldir islands during 2000-2010.

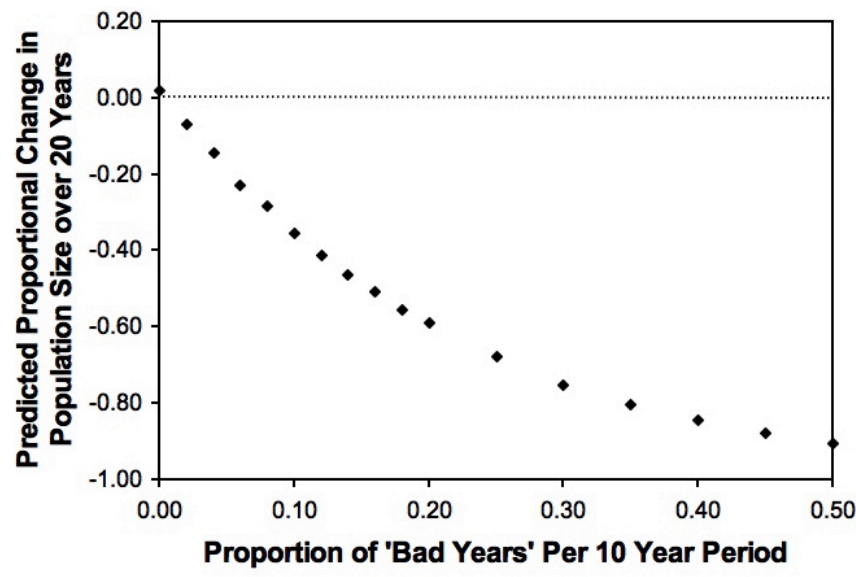

\section{DISCUSSION}

Least Auklets make up on average $11 \%$ of Norway rat diet at the Kiska Island auklet colony, but direct evidence of rat predation on Least Auklets is not abundant (Major et al. 2006, 2007, Eggleston 2010). Nevertheless, there are no other known significant threats to Least Auklets unique to Kiska Island, for example, no interactions with fisheries bycatch or light attraction, and although reproductive performance fluctuates somewhat due to variability in ocean productivity, cases of breeding failure are rare and not attributed to food availability (Major et al. 2006, Bond et al. 2012). Our population model revealed that both the Least Auklet mean $\lambda$ and $\log \lambda_{\mathrm{s}}$ at Kiska Island were not statistically different than those observed at rat-free colonies, but the mean annual change in population size was greatest at Kiska Island. It is important to note that our sample sizes at Kiska Island are low and this may contribute to our nonsignificant results. The alternative hypothesis that the observed stronger declines at Kiska Island are simply the result of lower vital rates cannot be rejected. However, given $\lambda$ is most sensitive to changes in annual adult survival and at Kiska Island, this variable was the highest and lowest observed among the three islands, i.e., displaying more variability than observed at Buldir and Kasatochi islands, the predicted population decline of Least Auklets breeding at Kiska Island is likely occurring because of increased variability in vital rates, not simply lower rates. The predicted $7 \%$ mean annual decrease in population size at Kiska Island is equivalent to losing $\sim 84,000$ breeding individuals each year, equivalent to $60 \%$ of the breeding population at Buldir Island, or almost six times the breeding population at Kasatochi Island.

Recent studies have linked oceanographic indices with seabird reproductive success and survival (Jones et al. 2002, 2007, Hipfner 2008, Wolf et al. 2009, Bond et al. 2011). As global climate changes, extremes in oceanographic conditions may become more frequent (Timmermann et al. 1999). There is very little variation in life history and breeding characteristics within temperate and polar seabirds, including Least Auklets, e.g., clutch size and timing of breeding. They are therefore less likely to be able to withstand perturbations caused by either introduced predators or changes in climatic or oceanographic conditions than species that exhibit a higher degree of biocomplexity in these characteristics (Hilborn et al. 2003). The additive effects of increased climate variability and introduced rats at Kiska Island may make this population extremely vulnerable. Furthermore, auklet demography at all three islands is affected by ocean climate and oceanography that forces North Pacific ocean productivity, and could explain population dynamics at all islands (Jones et al. 2002, Bond et al. 2011). Among the three islands included in this study, Kasatochi volcano erupted in 2008, following at least 100 years of dormancy, covering the colony site with a thick layer of ash and blocking most auklet crevices (Williams et al. 2010). At Kiska volcano, major eruptions in the 1960s produced virtually unlimited numbers of auklet breeding sites in the vast dome of porous lava at Sirius Point, where near complete breeding failure occurred in 2001 and 2002 in the presence of abundant introduced rats (Major et al. 2006). Such failure has never occurred on any island except Kiska (Bond 
et al. 2011). Thus, although the forecasted declines in auklet populations at Kasatochi and Buldir islands can be related to North Pacific-wide ocean productivity issues affecting all islands, or perhaps unknown local factors, such as gull predation or vegetation encroachment, the major demographic issue is limited to Kiska and is coincident with rats (Major et al. 2006).

Because Least Auklets apparently experience very similar environmental conditions across the Aleutian Islands (Bond et al. 2011, 2012), the only differences among Buldir, Kasatochi, and Kiska islands are the amount of available breeding habitat, i.e., rock crevices, and the presence of rats at Kiska Island. The auklet colonies at Buldir and formerly Kasatochi islands have experienced habitat loss because of encroaching vegetation. Qualitative estimates of this population decline at Buldir Island are approximately $20 \%$ over 20 years, for Least Auklets, (I. L. Jones, personal observation), similar to our model prediction of 26\% over 20 years. Arctic fox eradications at Kasatochi and Kiska islands, 1984 and 1987 respectively, likely had different effects. At Kasatochi Island, breeding birds were released from predation but encroaching vegetation limited their population, similar to our predicted decrease of $23 \%$ over 20 years. At Kiska Island, the eradication of introduced foxes likely released rats from predation pressure, escalating their effects on auklets, similar to our predicted decrease of $78 \%$ over 20 years.

The auklet colony at Kiska Island encompasses an area of approximately $2 \mathrm{~km}^{2}$ and is situated on two lava domes, one recent (1960s), the other older and from the 19th century (Coats et al. 1961, Simkin et al. 1981, Major et al. 2006). Although there are a very large number of birds breeding here and there are areas with encroaching vegetation, available habitat is presumably not limiting (authors' personal observations). Therefore, if rats had no effect on Least Auklets, we would expect the population trajectory at Kiska Island to be at least similar to that seen at Buldir and Kasatochi islands, or to show an increase as individuals emigrate from colonies with encroaching vegetation. Our model revealed large differences in projected population trends over 20 years between Kiska Island and the two other colonies, consistent with a factor unique to Kiska Island, such as predation and disturbance by introduced Norway rats.

Least Auklets sit at the slow end of the demographic 'slowfast' continuum; they are a 'survivor' or k-selected species exhibiting delayed reproduction and high investment in their offspring (Sæther et al. 1996). As our elasticity analysis confirmed, adult survival in this type of species is normally the most important vital rate determining $\lambda$. Our viability analysis demonstrated that with as little as a $10 \%$ chance of a 'bad year' occurring in any 10 -year period, i.e., years with $\lambda \leq 0.78$, which occurred in 2006 at Kiska Island, the population might experience a decline of at least $35 \%$ over 20 years, a foreboding projection in the face of increased climatic variation and the continued presence of rats.

Our results support the notion that introduced predators can have large negative effects on large seemingly healthy populations. Understanding how increased variance in demographic vital rates influences population growth rate is important for making management decisions. Specifically, the Least Auklet breeding population at Kiska Island is extremely important because it encompasses at least half of the Aleutian Islands' population, and about 4 to $6 \%$ of the global population of Least Auklets (Gaston and Jones 1998). Differences in spatial and temporal rat abundance and distribution, and the extreme size of the breeding auklet population at Kiska Island add complexity to this system, and may contribute to both under or over estimations of Least Auklet survival and fecundity at different parts of the auklet colony (Eggleston 2010). Because $\lambda$ was revealed to be most sensitive to estimates of adult survival, continued monitoring and assessment of this colony's viability is crucial, along with continued attention to the potential negative effects of increased variance in vital rates at this colony. Our results provide support for immediate actions to safeguard this important population through the eradication of introduced Norway rats. Because the Crested Auklet population at Kiska Island is similarly exposed (Bond et al. 2013), eradication would likely benefit this species as well as freeing this remote island's fragile ecosystem from the burden of this alien invasive predator.

The removal of introduced species from islands, including rats, is often considered one of the most powerful tools in conservation biology. To date, there have been over 787 successful animal eradications from over 582 islands, including 284 rodent eradications (Howald et al. 2007, Donlan and Wilcox 2008, Island Conservation 2010). Improving techniques and experience have led to successful eradications at sequentially larger islands, the largest being Campbell Island, New Zealand at 11,300 ha (McClelland and Tyree 2002). The successful eradication of rats in 2008 from Hawadax Island, formerly Rat Island (2671 ha), located 43 $\mathrm{km}$ southeast of Kiska Island, proved that rat eradication is feasible in the Western Aleutian Islands. Kiska Island, at 27,769 ha, is over twice the land area of Campbell Island, but is well within the island size for currently planned rat eradications, e.g., South Georgia Island, $167 \mathrm{~km}$ long with rat eradication commencing in 2012. Though a number of factors influence auklet populations, e.g., climate change and vegetation succession, introduced rats are the largest and most easily solvable problem.

Responses to this article can be read online at: http://www.ace-eco.org/issues/responses.php/564 


\section{Acknowledgments:}

We are sincerely grateful to numerous field technicians who helped collect the data used in this analysis at all three islands. Multiyear efforts of several people are indicated with a dagger (†). E. Andersen †, M. Barrett, D. Barton, G. Beyersdorf †, C. Brake, K. Brenneman, R. Buchheit †, D. Clutter, J. Daniels, E. Drew, B. Drummond †, A. Durand, J. Dussureault †, K. Elkin, C. Eggleston, J. Fischer†, J.C. Ford, S. Freemant, C. Gray, M. Grinnell, M. Hipfner, S. Hootman, N. Jones, T. Joyce†, P. Kappes, B. Keller, S. Kennedy, S. Kissler, H. Knechtel†, N. Konyukhov, S. Lantz, A. Larned, K. Lindquist, G. Loh, S. Lorenz, J. Marais, M. McClintock, L. Meehan, K. Morrison, J. Mueller, H. Munro †, M. Murphy†, R. Orben, M. Ortwerth, A. Palmer, L. Parker, A. Patrick, K. Payne, E. Penneyt, J. Petersen, D. Pirie-Hay, D. Rehder, H. Rennert, A. Ritchie, N. Rojek†, K. Russell, P. Ryan, G. Samson, S. Sapora, C. Schlawe, N. Seferovic, K. Shea, E. Sommer, L. Spitlert, A. Stoertz, A. Stover, S. Syria †, G. Thomson, S. Tucker, C. VanStratt, R. Walder, A. Wang, H. Walsh, and A. Will. We are especially grateful to the Alaska Maritime National Wildlife Refuge (AMNWR), who provided financial and logistical support. In particular, we would like to thank the captain and crews of the vessel Tiglax for providing transportation to Kiska Island and V. Byrd, A. Sowls, L. Spitler, and J. Williams for their invaluable guidance and aid throughout this study. Thanks to A. Edwards, B. Roitberg, G. Robertson, and A. Chubaty for helpful comments and guidance with this model and MATLAB, and anonymous reviewers for comments on earlier versions of this manuscript. The Natural Sciences and Engineering Research Council of Canada, North Pacific Research Board, Alaska Maritime National Wildlife Refuge, and Northern Scientific Training Program of the Department of Aboriginal Affairs and Northern Development of Canada provided financial support for this research.

\section{LITERATURE CITED}

Akaike, H. 1974. A new look at the statistical model identification. IEEE Transactions on Automatic Control 19:716-723.

Anderson, D. R., and K. P. Burnham. 1999. General strategies for the analysis of ringing data. Bird Study 46:261-270. http:// dx.doi.org/10.1080/00063659909477253

Bédard, J. 1969. Feeding of Least, Crested, and Parakeet Auklets around St. Lawrence Island, Alaska. Canadian Journal of Zoology 47:1025-1050. http://dx.doi.org/10.1139/z69-166

Bond, A. L., and I. L. Jones. 2008. Demography of auklets Aethia spp. in relation to introduced Norway rats Rattus norvegicus at Kiska Island, Aleutian Islands, Alaska in 2008. U.S. Fish and Wildlife Service Report AMNWR, Homer, Alaska, USA.
Bond, A. L., I. L. Jones, S. S. Seneviratne, and S. B. Muzaffar. 2013. Least Auklet (Aethia pusilla). In A. Poole, editor. The birds of North America, Number 69. Cornell Lab of Ornithology, Ithaca, New York, USA.

Bond, A. L., I. L. Jones, W. J. Sydeman, H. L. Major, S. Minobe, J. C. Williams, and G. V. Byrd. 2011. Reproductive success of planktivorous seabirds in the North Pacific is related to ocean climate on decadal scales. Marine Ecology Progress Series 424:205-218. http://dx.doi.org/10.3354/meps08975

Bond, A. L., I. L. Jones, J. C. Wiliams, and G. V. Byrd. 2012. Diet of auklet chicks in the Aleutian Islands, Alaska: similarity among islands, interspecies overlap, and relationships to ocean climate. Journal of Ornithology 153:115-129. http://dx.doi. org/10.1007/s10336-011-0704-3

Bond, A. L., I. L. Jones, J. C. Williams, and G. V. Byrd. 2013. Survival and reproductive success of Crested Auklets (Aethia cristatella) in the presence of introduced Norway rats (Rattus norvegicus). Marine Ornithology, in press.

Buchheit, R. M., and J. C. Ford. 2008. Biological monitoring in the Aleutian Islands, Alaska in 2008: summary appendices. U.S. Fish and Wildlife Service Report AMNWR 08/12, Homer, Alaska, USA. [online] URL: http://avo.alaska.edu/ downloads/reference.php?citid $=4483$

Burnham, K. P., and D. R. Anderson. 2002. Model selection and multimodel inference: a practical information-theoretic approach. Second edition. Springer-Verlag, New York, New York, USA.

Byrd, G. V., H. M. Renner, and M. Renner. 2005. Distribution patterns and population trends of breeding seabirds in the Aleutian Islands. Fisheries Oceanography 14:139-159. http:// dx.doi.org/10.1111/j.1365-2419.2005.00368.x

Caswell, H. 2001. Matrix population models: construction, analysis, and interpretation. Second edition. Sinauer Associates, Sunderland, Massachusetts, USA.

Coats, R. R., W. H. Nelson, R. Q. Lewis, and H. A. Powers. 1961. Geologic reconnaissance of Kiska Island, Aleutian Islands, Alaska. U.S. Government Printing Office. Washington, D. C., USA.

Doak, D. F., W. F. Morris, C. Pfister, B. E. Kendall, and E. M. Bruna. 2005. Correctly estimating how environmental stochasticity influences fitness and population growth. American Naturalist 166:E14-E21. http://dx.doi.org/10.1086/430642

Donlan, C. J., and C. Wilcox. 2008. Integrating invasive mammal eradications and biodiversity offsets for fisheries bycatch: conservation opportunities and challenges for seabirds and sea turtles. Biological Invasions 10:1053-1060. http://dx.doi.org/10.1007/s10530-007-9183-0 
Ebbert, S., and G. V. Byrd. 2002. Eradications of invasive species to restore natural biological diversity on Alaska Maritime National Wildlife Refuge. Pages 102-109 in C. R. Veitch, and M. N. Clout, editors. Turning the tide: the eradication of invasive species. IUCN SSC Invasive Species Specialist Group. International Union for the Conservation of Nature, Gland, Switzerland.

Eggleston, C. 2010. Ecology of Norway rats (Rattus norvegicus) in relation to conservation and management of seabirds on Kiska Island, Aleutian Islands, Alaska 2005-2006. Thesis. Memorial University of Newfoundland, St. John's, Newfoundland, Canada.

Gaston, A. J., and I. L. Jones. 1998. The auks: Alcidae. Oxford University Press, New York, New York, USA.

Hedgren, S. 1980. Reproductive success of guillemots Uria aalge on the island of Stora Karlso. Ornis Fennica 57:49-57.

Heppell, S. S., H. Caswell, and L. B. Crowder. 2000. Life histories and elasticity patterns: perturbation analysis for species with minimal demographic data. Ecology 81:654-665. http://dx.doi.org/10.1890/0012-9658(2000)081[0654:LHAEPP] 2.0.CO;2

Hilborn, R., T. P. Quinn, D. E. Shindler, and D. E. Rogers. 2003. Biocomplexity and fisheries sustainability. Proceedings of the National Academy of Sciences of the United States of America 100:6564-6568. http://dx.doi.org/10.1073/pnas.1037274100

Hipfner, J. M. 2008. Matches and mismatches: ocean climate, prey phenology and breeding success in a zooplanktivorous seabird. Marine Ecology Progress Series 368:295-304. http:// dx.doi.org/10.3354/meps07603

Howald, G., C. J. Donlan, J. P. Galvan, J. C. Russell, J. Parkes, A. Samaniego, Y. Wang, D. Veitch, P. Genovesi, M. Pascal, A. Saunders, and B. Tershy. 2007. Invasive rodent eradications on islands. Conservation Biology 21:1258-1268. http://dx.doi. org/10.1111/j.1523-1739.2007.00755.x

Island Conservation. 2010. Global islands invasive vertebrate eradication database. Island Conservation, Santa Cruz, California, USA.

Jones, I. L. 1992. Colony attendance of Least Auklets at St. Paul Island, Alaska - implications for population monitoring. Condor 94:93-100. http://dx.doi.org/10.2307/1368799

Jones, I. L. 1993. Sexual differences in bill shape and external measurements of Crested Auklets. Wilson Bulletin 105:525-529.

Jones, I. L., F. M. Hunter, and G. J. Robertson. 2002. Annual adult survival of Least Auklets (Aves, Alcidae) varies with large-scale climatic conditions of the North Pacific Ocean. Oecologia 133:38-44. http://dx.doi.org/10.1007/s00442-002-0991-8
Jones, I. L., F. M. Hunter, G. J. Robertson, J. C. Williams, and G. V. Byrd. 2007. Covariation among demographic and climate parameters in Whiskered Auklets Aethia pygmaea. Journal of Avian Biology 38:450-461. http://dx.doi. org/10.1111/j.0908-8857.2007.03895.x

Jones, I. L., and R. Montgomerie. 1992. Least Auklet ornaments - do they function as quality indicators. Behavioral Ecology and Sociobiology 30:43-52. http://dx.doi.org/10.1007/ $\underline{\mathrm{BF} 00168593}$

Knudtson, E. P., and G. V. Byrd. 1982. Breeding biology of Crested, Least, and Whiskered Auklets on Buldir Island, Alaska. Condor 84:197-202. http://dx.doi.org/10.2307/1367671

Kondratyev, A. Y., N. M. Litvinenko, Y. V. Shibaev, P. S. Vyatkin, and L. F. Kondratyeva. 2000. The breeding seabirds of the Russian Far East. Pages 37-82 in A. Y. Kondratyev, N. M. Litvinenko, and G. W. Kaiser, editors. Seabirds of the Russian Far East. Canadian Wildlife Service Special Publication, Ottawa, Ontario, Canada.

Lebreton, J. D., K. P. Burnham, J. Clobert, and D. R. Anderson. 1992. Modeling survival and testing biological hypotheses using marked animals: a unified approach with case-studies. Ecological Monographs 62:67-118. http://dx.doi. org/10.2307/2937171

Lefkovitch, L. P. 1965. The study of population growth in organisms grouped by stages. Biometrics 21:1-18. http://dx. doi.org/10.2307/2528348

Lewontin, R. C., and D. Cohen. 1969. On population growth in a randomly varying environment. Proceedings of the National Academy of Sciences of the United States of America 62:1056-1060. http://dx.doi.org/10.1073/pnas.62.4.1056

Major, H. L., and I. L. Jones. 2005. Distribution, biology and prey selection of the introduced Norway rat Rattus norvegicus at Kiska Island, Aleutian Islands, Alaska. Pacific Conservation Biology 11:105-113.

Major, H. L., I. L. Jones, G. V. Byrd, and J. C. Williams. 2006. Assessing the effects of introduced Norway rats (Rattus norvegicus) on survival and productivity of Least Auklets (Aethia pusilla). Auk 123:681-694. http://dx.doi. org/10.1642/0004-8038(2006)123[681:ATEOIN]2.0.CO;2

Major, H. L., I. L. Jones, M. R. Charette, and A. W. Diamond. 2007. Variations in the diet of introduced Norway rats (Rattus norvegicus) inferred using stable isotope analysis. Journal of Zoology (London) 271:463-468. http://dx.doi.org/10.1111/ j.1469-7998.2006.00230.x

Mathworks. 2007. MATLAB, version 7.4.0. Mathworks, Natick, Massachusetts, USA.

McClelland, P., and P. Tyree. 2002. Eradication: the clearance of Campbell Island. New Zealand Geographic 58:86-94. 
Morris, W. F., and D. F. Doak. 2002. Quantitative conservation biology: theory and practice of population viability analysis. Sinauer Associates, Sunderland, Massachusetts, USA.

Morris, W. F., S. Tuljapurkar, C. V. Haridas, E. S. Menges, C. C. Horvitz, and C. A. Pfister. 2006. Sensitivity of population growth rate to demographic variability within and between phases of the disturbance cycle. Ecology Letters 9:1331-1341. http://dx.doi.org/10.1111/j.1461-0248.2006.00988.x

Murie, O. J. 1959. Fauna of the Aleutian Islands and Alaska Peninsula. U.S. Fish and Wildlife Service, Washington, D. C., USA. http://dx.doi.org/10.3996/nafa.61.0001

Payne, K. J. 2008. Biological monitoring at Buldir Island, Alaska in 2008: summary appendices. U.S. Fish and Wildlife Service Report AMNWR 08/12, Homer, Alaska, USA.

Piatt, J. F., B. D. Roberts, and S. A. Hatch. 1990. Colony attendance and population monitoring of Least and Crested Auklets on St. Lawrence Island, Alaska. Condor 92:97-106. http://dx.doi.org/10.2307/1368387

Rayner, M. J., M. E. Hauber, M. J. Imber, R. K. Stamp, and M. N. Clout. 2007. Spatial heterogeneity of mesopredator release within an oceanic island system. Proceedings of the National Academy of Sciences of the United States of America 104:20862-20865. http://dx.doi.org/10.1073/pnas.0707414105

SAS Institute. 2008. SAS/STAT® 9.2 User's Guide. SAS Institute, Cary, North Carolina, USA.

Sæther, B. E., T. H. Ringsby, and E. Røskaft. 1996. Life history variation, population processes and priorities in species conservation: towards a reunion of research paradigms. Oikos 77:217-226. http://dx.doi.org/10.2307/3546060

Simkin, T., L. Seibert, L. McCelland, D. Bridge, C. Newhall, and J. H. Latter. 1981. Volcanoes of the world a regional directory, gazetteer and chronology of volcanism during the last 10,000 years. Hutchinson Ross, Stroudsburg, Pennsylvania, USA.

Timmermann, A., J. Oberhuber, A. Bacher, M. Esch, M. Latif, and E. Roeckner. 1999. Increased El Niño frequency in a climate model forced by future greenhouse warming. Nature 398:694-697. http://dx.doi.org/10.1038/19505

Tucker, S. J., A. P. Will, A. X. Wang, and B. A. Drummond. 2010. Biological monitoring at Buldir Island, Alaska in 2010. U.S. Fish and Wildlife Service Report AMNWR, Homer, Alaska, USA.

White, G. C., and K. P. Burnham. 1999. Program MARK: survival estimation from populations of marked animals. Bird Study 46:120-139. http://dx.doi.org/10.1080/00063659909477239

Wiese, F. K., G. J. Robertson, and A. J. Gaston. 2004. Impacts of chronic oil pollution and the murre hunt in Newfoundland on Thick-billed Murre Uria lomvia populations in the eastern
Canadian Arctic. Biological Conservation 116:205-216. http://dx.doi.org/10.1016/S0006-3207(03)00191-5

Williams, J. C., B. A. Drummond, and R. T. Buxton. 2010. Initial effects of the August 2008 volcanic eruption on breeding birds and marine mammals at Kasatochi Island, Alaska. Arctic, Antarctic, and Alpine Research 42:306-314. http://dx.doi.org/10.1657/1938-4246-42.3.306

Wolf, S. G., W. J. Sydeman, J. M. Hipfner, C. L. Abraham, B. R. Tershy, and D. A. Croll. 2009. Range-wide reproductive consequences of ocean climate variability for the seabird Cassin's Auklet. Ecology 90:742-753. http://dx.doi. org/10.1890/07-1267.1 
Appendix 1 Population projection matrices built using demographic parameters on Buldir (1990 - 2010), Kasatochi (1996 - 2007), and Kiska (2001 - 2010) islands, Alaska.

\begin{tabular}{|c|c|c|c|c|c|c|}
\hline Island & Year & $\begin{array}{c}P_{1} \\
\text { (juvenile } \\
\text { survival) }\end{array}$ & $\begin{array}{c}F_{2} \\
\text { (adult } \\
\text { fecundity) }\end{array}$ & $\begin{array}{c}G_{1} \\
\text { (maturation) }\end{array}$ & $\begin{array}{c}P_{2} \\
\text { (adult } \\
\text { survival) }\end{array}$ & $\begin{array}{c}\lambda \\
\text { (population } \\
\text { growth rate) }\end{array}$ \\
\hline \multirow[t]{18}{*}{ Buldir } & 1991 & 0.4114 & 0.2172 & 0.3428 & 0.7542 & 0.9050 \\
\hline & 1992 & 0.4597 & 0.1897 & 0.3950 & 0.8548 & 0.9948 \\
\hline & 1993 & 0.3603 & 0.1759 & 0.3033 & 0.6635 & 0.7882 \\
\hline & 1994 & 0.4324 & 0.1429 & 0.3806 & 0.8130 & 0.9237 \\
\hline & 1995 & 0.5159 & 0.2474 & 0.4353 & 0.9511 & 1.1273 \\
\hline & 1996 & 0.4461 & 0.2098 & 0.3773 & 0.8234 & 0.9735 \\
\hline & 1997 & 0.5235 & 0.2094 & 0.4514 & 0.9749 & 1.1306 \\
\hline & 1998 & 0.3811 & 0.1574 & 0.3274 & 0.7085 & 0.8247 \\
\hline & 2000 & 0.4845 & 0.1683 & 0.4243 & 0.9087 & 1.0377 \\
\hline & 2001 & 0.5071 & 0.1948 & 0.4393 & 0.9464 & 1.0926 \\
\hline & 2002 & 0.4801 & 0.2111 & 0.4095 & 0.8896 & 1.0431 \\
\hline & 2003 & 0.4908 & 0.1187 & 0.4445 & 0.9354 & 1.0328 \\
\hline & 2004 & 0.4412 & 0.1868 & 0.3779 & 0.8192 & 0.9563 \\
\hline & 2005 & 0.4739 & 0.2111 & 0.4035 & 0.8775 & 1.0305 \\
\hline & 2006 & 0.5035 & 0.2639 & 0.4200 & 0.9236 & 1.1072 \\
\hline & 2007 & 0.3994 & 0.2328 & 0.3283 & 0.7277 & 0.8851 \\
\hline & 2008 & 0.4401 & 0.2146 & 0.3706 & 0.8107 & 0.9628 \\
\hline & 2009 & 0.4625 & 0.2603 & 0.3821 & 0.8445 & 1.0222 \\
\hline \multirow[t]{10}{*}{ Kasatochi } & 1997 & 0.5034 & 0.1933 & 0.4361 & 0.9395 & 1.0846 \\
\hline & 1998 & 0.4103 & 0.1740 & 0.3514 & 0.7618 & 0.8894 \\
\hline & 1999 & 0.4599 & 0.1618 & 0.4022 & 0.8622 & 0.9858 \\
\hline & 2000 & 0.4506 & 0.2332 & 0.3765 & 0.8270 & 0.9898 \\
\hline & 2001 & 0.4684 & 0.2690 & 0.3859 & 0.8543 & 1.0369 \\
\hline & 2002 & 0.4749 & 0.1814 & 0.4116 & 0.8865 & 1.0228 \\
\hline & 2003 & 0.4775 & 0.2559 & 0.3972 & 0.8747 & 1.0517 \\
\hline & 2004 & 0.4842 & 0.1856 & 0.4195 & 0.9037 & 1.0430 \\
\hline & 2005 & 0.4059 & 0.1362 & 0.3567 & 0.7626 & 0.8678 \\
\hline & 2006 & 0.4364 & 0.1554 & 0.3811 & 0.8175 & 0.9360 \\
\hline \multirow[t]{7}{*}{ Kiska } & 2002 & 0.4326 & 0.0325 & 0.4177 & 0.8503 & 0.8806 \\
\hline & 2003 & 0.4883 & 0.1750 & 0.4262 & 0.9145 & 1.0478 \\
\hline & 2004 & 0.4254 & 0.1839 & 0.3635 & 0.7890 & 0.9233 \\
\hline & 2006 & 0.3542 & 0.1915 & 0.2942 & 0.6484 & 0.7805 \\
\hline & 2007 & 0.5129 & 0.2054 & 0.4422 & 0.9551 & 1.1078 \\
\hline & 2008 & 0.3840 & 0.2252 & 0.3154 & 0.6995 & 0.8515 \\
\hline & 2009 & 0.4132 & 0.1548 & 0.3589 & 0.7721 & 0.8889 \\
\hline
\end{tabular}

